\section{Congenital Narcotic Addiction Sir,}

It might interest Dr. G. P. McMullin and A. N. Mobarak (authors of Congenital Narcotic Addiction, Archives of Disease in Childhood, 45, 140) and your readers to know that another instance of neonatal narcotic addiction was recorded in this country in January 1968 (Midwives Chronicle and Nursing Notes-the details appear on p. 10 in the article on 'Drug Abuse and Pregnancy' by Dr. S. Caruana.) The baby was looked after in the Special Care Nursery at St. Thomas' Hospital, under Dr. Dennis Cottom. Chlorpromazine (and for a short period, phenobarbitone in addition) was sufficient treatment in our case.

C. G. H. NewMaN

Westminster Hospital

St. John's Gardens

London $S W 1$

\section{Fibrin/Fibrinogen Degradation Products}

Sir,

Uttley, Allan, and Cash (1969) have performed a useful service in determining levels of fibrin/fibrinogen degradation products (FDP) in the sera of normal children. In expressing their results they have, however, neglected the fact that the affinity of FDP for fibrinogen antibody is not uniform but depends on their molecular size (Fox et al., 1965; Catt et al., 1968). Early breakdown products of fibrin have a greater affinity for fibrinogen antibody than the later breakdown products D and E (Catt et al., 1968), and further the haemagglutination inhibition system may not detect the presence of the smallest molecular weight antigenic determinants $\mathrm{E}$ if they are not also associated with higher molecular weight split products (Rayner et al., 1969). In view of this, the tanned red cell haemagglutination inhibition assay for FDP is only a semi-quantitative determination and the results are best expressed as the dilution of serum which inhibits agglutination rather than a quantitative measurement, namely $\mu \mathrm{g} . / \mathrm{ml}$. It would, therefore, be of value if the authors could express their results in terms of the dilution of sera so that other workers in this field could compare their findings with them.

HENRY EKERT*

Institute of Child Health

30 Guilford Street

London WC1

REFERENCES

Catt, K. J., Hirsh, J., Castelan, D. J., Niall, H. D., and Tregear, G. W. (1968). Radioimmunoassay of fibrinogen and its proteolysis products. Thrombosis et Diathesis Haemorrhagica, 20, 1.

*Present address : Department of Haematology, Royal Children's Hospital, Flemington Road, Parkville, Victoria 3052, Australia.
Fox, F. J., Wide, L., Killander, J., and Gemzell, C. (1965). Determination of fibrinogen and fibrinolysis products in human plasma by an immunological method. Scandinavian fournal of Clinical and Laboratory Investigation, 17, 341.

Rayner, H., Paraskevas, F., Israels, L. G., and Israels, E. D. (1969). Fibrinogen breakdown products: identification and assay in serum and urine. Fournal of Laboratory and Clinical Medicine, $74,586$.

Uttley, W. S., Allan, A. G. E., and Cash, J. D. (1969). Fibrin/ fibrinogen degradation products in sera of normal infants and children. Archives of Disease in Childhood, 44, 761.

Drs. Uttley, Cash, and Allan comment as follows: We are grateful to Dr. Ekert for his interesting observations. We have previously commented on the problem of the possible heterogenicity of different anti-fibrinogen sera, in terms of sensitivity to $\mathrm{D}$ and $\mathrm{E}$ products (Cash $e t$ al.,1969), and agree that such a study would be well worth while, particularly in the light of the investigations of Rayner et al. (1969). However, no such heterogenicity has been apparent in the 4 batches of antisera we have used over the past 3 years, but it must be admitted that they have all come from the same Company.

We do not accept that results expressed in terms of dilution of test sera would be of much value to others in this field. Experience has shown us that the batch variation in terms of sensitivity to a standard fibrinogen preparation can be quite large. Thus the same test serum might give an end-point with one batch of cells at $1 / 24$ and with another at $1 / 6$. Probably the single most important requirement for Dr. Ekert's admirable desire for comparableness is the availability of an international fibrinogen standard. (Perhaps as a start we could all use the Wellcome Reagents Ltd. fibrinogen standard.) Certainly expressing results in dilutions of sera without declaring the sensitivity of the immunoassay would be of little help in this exercise.

W. S. Uttrey, A. G. E. Allan, and J. D. Cash

Department of Child Life and Health

University of Edinburgh, 17 Hatton Place

Edinburgh 1UW

REFERENCES

Cash, J. D., Woodfield, D. G., Cole, S. K., Allan, A. G. E., and Das, P. C. (1969). Fibrinolytic enzyme system. British Medical fournal, 4, 50.

Rayner, H., Paraskevas, F., Israels, L. G., and Israels, D. E. (1969). Fibrinogen breakdown products: identification and assay in serum and urine. Fournal of Laboratory and Clinical Medicine, $74,586$.

\section{Phenylketonuria Some Current Problems}

Sir,

Readers interested in phenylketonuria may be surprised to see Komrower's statement in this journal $(1970,45,2)$ that I suggest that a serum phenylalanine level below $12 \mathrm{mg} . / 100 \mathrm{ml}$. is satisfactory for intellectual growth. In our paper $(1970,45,5) \mathrm{my}$ co-authors and 